was so excellent a man, so bright and genial, so kindly in his intercourse with those around him, so upright and pure in character, so installed in the confidence of people who knew him, that his loss came home to all as a personal one. Every good wish had gone with him at his enlistment, though he had no relatives in the county. He was a New England boy, raised with good habits, prudent, industrious and praiseworthy. Even yet he must be remembered in great kindness by the old settlers. We believe he was the first man killed from that county-certainly the first from Webster City.

We have always taken good care of that useful little piece of plain, home-made furniture, and seeing it brings to mind the handsome young pioneer who constructed it. We prize it for his sake, and some day we may search for his grave near the spot where he fell.

\title{
THE BOUNDARY BETWEEN IOWA AND MISSOURI.
}

This subject having been under discussion of late, with only a partial disclosure of its history, we have secured from Mr. Frank E. Landers, author of the Historical-Geographical Atlas heretofore mentioned in THE Ansals, an article wherein he lucidly sets forth the various official acts which resulted in the establishment of our southern boundary. This, we believe, presents for the first time the full history of its establishment, and is therefore of permanent value as a historical document.

On the other hand, Ex-Senator Alfred Hebard, of Red Oak, Montgomery County, gives the reader his own personal recollections of "the bloody war" which at one time seemed imminent between Iowa and Missouri over this question. He had the honor of being commissioned Captain, by Governor Robert Lucas, with orders to raise a company of men for this "service on the border." Happily, however, the controversy was settled amicably without an appeal to arms. These articles are valuable as throwing light upon interesting epi$8-6$ 
sodes in the early history of our State which are now almost forgotten. Beyond the fact of the irregularity of this boundary, and that it was for a time a serious bone of contention between Iowa and Missouri, little definite knowledge has been accessible to the general reader. It has been necessary to dig this information out of musty old documents, the acts of Congress and the Legislatures of Iowa and Missouri, and decisions of the Supreme Court of the United States. We also have the promise of another article, in which the question will be treated from quite a different standpoint.

\section{JUSTICE TO EDWARD RUSSELL.}

In Mr. Gue's interesting sketch of the life and public services of Hiram Price, he pays a deserved tribute to that distinguished gentleman for his aid in "striking out the word white" from the constitution of our State. But while mentioning the author of the movement-Mr. Edward Russell, of The Davenport Gazette-we hardly think he renders full justice to him as its originator and defender. The writer was in that convention and believes that he remembers the circumstances yery clearly. There had been more or less discussion of the subject of impartial suffrage in the general press and througi. out the country, but it was one of those vexed questions upon which there was far from being unanimity of feeling, even amongst those who fought against the rebellion. In the Republican State Convention of 1865, Edward Russell was a member of the committee on resolutions, and during its deliberations offered a proposition to "strike out the word white." The committee rejected his proposition and reported the following as its recommendation on the suffrage question:

\footnotetext{
"That with proper safeguards to the purity of the ballot box, the elective franchise should be based upon loyalty to the Constitution and the Union, recognizing and affirming the equality of all men before the law."
}

But when the resolutions were reported to the convention Mr. Russell moved his famous amendment, as follows:

\footnotetext{
"Therefore, we are in favor of amending the Constitution of our State by striking out the word white in the article on suffrage."
} 
Copyright of Annals of Iowa is the property of State of Iowa, by \& through the State Historical Society of Iowa and its content may not be copied or emailed to multiple sites or posted to a listserv without the copyright holder's express written permission. However, users may print, download, or email articles for individual use. 